\title{
Penyingkapan Makna Harga di Kontes Bandeng pada Tradisi Lelang Bandeng Gresik
}

\author{
Habibah Mashumah', Tumirin ${ }^{2 *}$ \\ ${ }^{1,2}$ Universitas Muhammadiyah Gresik
}

\begin{abstract}
The purpose of this research was to find the meaning of price at Bandeng Contest event in Gresik city. The milkfish contest was a milkfish competition held on the night of twenty-nine every Ramadan. The study used a qualitative approach. Transcendental phenomenological methods were used to analyze data. The number of research informants was five people. The informants were four additional farmers and one buyer who won the contest. Interviews were used to obtain research data. The research found the meaning of milkfish contest to increase the income / prosperity of farmers of ponds.
\end{abstract}

Keywords: milkfish contest, milkfish, fisherman, selling price.

Tipe artikel: Empiris

\section{Pendahuluan}

\subsection{Latar Belakang Masalah}

Menjalankan sebuah bisnis jual-beli tidak akan terlepas dari permasalahan harga. Harga memegang peranan penting dalam terjadinya kesepakatan jual-beli dari produsen ke tangan konsumen. Melalui penetapan harga, akan terlihat posisi kelayakan produk dari nilai ekonomisnya. Karena permasalahan ini, perusahaan biasanya mengadakan penetapan harga yang disepakati sebelum barang beredar di pasaran.

Untuk sebuah proses penetapan harga, suatu bisnis harus memiliki wawasan tentang kondisi produk, keuangan, dan hasil akhir berupa profit atau keuntungan yang ingin dicapai. Untuk mengetahui semua proses ini dengan baik, maka suatu bisnis membutuhkan perhitungan akuntansi yang tidak hanya memuat angka-angka nominal pengeluaran dan pemasukan, namun juga sistem akuntansi yang mampu menyajikan suatu prediksi berbentuk tabel maupun grafik data untuk memudahkan penilaian secara cepat dan akurat.

Harga unik yang terjadi di Gresik yaitu tradisi yang berhubungan dengan mata pencaharian sebagian besar masyarakat Gresik yaitu pertambakan. Tradisi tersebut dinamakan Pasar Bandeng dimana hanya dilaksanakan setahun sekali pada 2 hari sebelum hari raya Idul Fitri atau malam songolikur, tradisi ini bertujuan untuk melestarikan kebudayaan daerah serta mengangkat perekonomian masyarakat Gresik. Pasar Bandeng berbeda dengan pasar ikan biasa, mengingat acara utama Pasar Bandeng adalah "Lelang Bandeng." Banyak pejabat dan orang kaya yang menghadiri acara tersebut. Ikan bandeng yang diperjualbelikan di acara tersebut merupakan bandeng-bandeng

\footnotetext{
${ }^{*}$ Penulis yang sesuai:

E-mail: tumirin@umg.ac.id

Afiliasi: Universitas Muhammadiyah Gresik
} 
berkualitas yang berukuran besar. Harganya pun bervariasi mulai dari Rp2.000.000 sampai Rp8.000.000 per ekor.

Harga yang mungkin tak kalah unik lainnya adalah harga dari lelang bandeng di Sidoarjo, karena bandeng dengan berat kisaran diatas $4 \mathrm{Kg}$ dibandrol dengan harga puluhan bahkan ratusan juta rupiah. Berbeda dengan lelang bandeng di Gresik yang dilaksanakan di bulan ramadhan, di Sidoarjo Tradisi lelang bandeng terus diadakan rutin setiap setahun sekali saat Bulan Maulud. Bandeng yang digunakan biasanya bandeng dengan berat diatas $4 \mathrm{~kg}$ yang disebut bandeng kawak. Berdasarkan kondisi tersebut pemerintah Kabupaten Sidoarjo berinisiatif untuk mengadakan kegiatan yang bermanfaat, yakni lelang bandeng tradisional. Kegiatan ini diadakan agar masyarakat Sidoarjo dapat menyadari bahwa, kekayaan alam tambak bandeng Sidoarjo sangat melimpah. Tujuan lainnya agar petani tambak termotivasi untuk terus meningkatkan kualitas budidaya tambaknya. Kegiatan ini juga merupakan upaya nyata dalam memadukan antara konsep religi dan konsep ekonomi. Lelang bandeng diadakan berbeda dengan proses pelelangan ikan pada umumnya.

Lelang bandeng menjadi bukti bahwa sebuah tradisi lokal yang dikembangkan secara kreatif akan mampu memberikan manfaat secara ekonomis bagi masyarakat Sidoarjo. Penting bagi masyarakat untuk mengerti, memahami dan melaksanakan tradisi tersebut sebagai bentuk upaya pelestariannya. Lelang bandeng memiliki nilai-nilai yang bagus misalnya pelestarian tradisi lokal, gotong royong dan semangat berprestasi berdasarkan profesi.

Para petani tambak bandeng di acara lelang memiliki perspektif tersendiri dalam memaknai harga yang harus dikeluarkan untuk ikan bandeng jika dibandingkan dengan perspektif akuntansi, ada pemaknaan tertentu bagi petambak bandeng lelangan dengan harga mahal. Nilai lebih tersebut perlu diungkapkan dengan melakukan penelitian kepada para informan yang tepat dengan melakukan penelitian menggunakan pendekatan Fenomenologi (Tumirin dan Abdurahim, 2015). Penelitian ini bertujuan untuk mengungkapkan makna harga yang tersembunyi dalam ikan bandeng lelangan. Hasil dari penelitian ini diharapkan bisa memberikan tambahan pengetahuan dibidang akuntansi bahwa biaya akan memiliki makna yang berbeda jika dilihat dari perspektif yang berbeda.

\subsection{Rumusan Masalah}

Rumusan masalah dalam penelitian ini adalah "Apa makna harga yang terkandung dalam lelangan Bandeng di Pasar Bandeng Gresik?”

\subsection{Tujuan Penelitian}

Tujuan penelitian ini adalah mengungkapkan makna harga yang terkandung dalam lelangan Bandeng di Pasar Bandeng Gresik.

\section{Metodologi Penelitian Fenomenologi}

Fenomenologi berasal dari bahasa Yunani phainomai yang berarti "menampak." Fenomena merupakan fakta yang disadari dan masuk dalam pemahaman manusia. Fenomena merupakan kesadaran dan disajikan dalam kesadaran, bukan yang tampak secara kasat mata saja. Fenomenologi menggambarkan pengalaman manusia yang terkait dengan objek (Kuswarno, 2009).

Bagi Husserl makna "realitas" merupakan perluasan dari kata "nature." Maknanya nature science menggunakan realitas sebagai keseluruhan benda dalam ruang dan waktu. Namun Husser membalik persoalan filsafat dari objek ke subjek pengetahuan. Hal tersebut berasal dari pandangan Descrates tentang "aku yang berfikir" atau "cogito ergo sum."(Adian, 2010). Filsafat membahas empat bidang yakni ontologi, epistemologi, etika, dan logika. Ditinjau dari ontologi fenomenologi mempelajari sifat-sifat alami kesadaran. Fenomenologi membawa ke dalam permasalahan mendasar jiwa dan raga. Persoalan jiwa raga ini dipecahkan dengan bracketing method. Sebagai pengembangan Husserl membuat teori pengandaian mengenai "keseluruhan dan bagiannya" hubungan keseluruhan dan bagian dan teori tentang makna ideal (Kuswarno, 2009).

Sumbangan metodis terbesar Husserl dalam filsafat adalah epoche yaitu metode penundaan asumsi realitas sehingga memunculkan hakikat. Maksudnya adalah bahwa kita tidak boleh berasumsi terhadap realitas tetapi realitas yang benar berdasarkan pengalaman orang yang mengalami realitas 
tersebut (Adian, 2010), Reduksi yang digunakan adalah: reduksi fenomenologis, reduksi eiditis, dan reduksi transendental (Kuswarno, 2009)

Kesadaran murni adalah tempat untuk mengkonstitusikan atau menyusun objek yang diamati. Pada tahap ini objek mengalami kesadaran dirinya sendiri dan kebenaran yang dicapai adalah kesesuaian antara realitas dan pikiran. Fenomenologi epistemologi mengeluarkan makna dari sesuatu yang meterial (Kuswarno, 2009).

Fenomenologi dan logika Husserl membawa teori kesengajaan yang menjadi jantung fenomenologi. Kesengajaan dan tekanan semantik dari sebuah makna ideal dan proposisi berpusat pada logika. Logika yang terstruktur dapat ditemukan pada bahasa, baik bahasa sehari-hari maupun simbolsimbol. Maka bahasa membawa pengalaman dan makna dari pengalaman tersebut. Sehingga erat kaitannya antara fenomenologi dan teori logika bahasa (Kuswarno, 2009).

Fenomenologi dan etika memainkan peran penting dengan menawarkan analisis terhadap kehendak, penilaian, kebahagiaan, dan perhatian pada orang lain. Husserl menempatkan etika sebagai dasar dalam filsafat. Secara khusus Husserl menempatkan phenomenology of sympathi dan dalam etika (Kuswarno, 2009).

Husserl sangat tertarik dengan penemuan makna dan hakikat dari pengalaman dan membedakan fakta dan esensi dalam fakta maka secara metodologis fenomenologis menjelaskan thing in themselves, mengetahui apa yang masuk sebelum kesadaran dam memahami makna dan esensinya dalam intuisi dan refleksi diri. Proses transformasi dari pengalaman empiris ke makna esensi ini dinamakan "ideation." Ideation menjelaskan objek yang muncul dalam kesadaran bersatu dengan objek itu sendiri untuk dijadikan makna dalam ilmu pengetahuan. Oleh karena itu, terdapat hubungan objek nyata dengan objek kesadaran. Kesadaran itu yang disebut sebagai realitas sebenarnya (Kuswarno, 2009).

Komponen-komponen konseptual dari fenomenologi Husserl menurut (Kuswarno, 2009) adalah: (1) kesengajaan (intentionality); (2) Noema dan Noesis; (3) Intuisi; (4) Intersubjektivitas. Fenomenologi transendental merupakan studi mengenai penampakan fenomena seperti dalam kesadaran. Fenomenologi transendental memberikan kesempatan untuk menjelaskan fenomena dalam istilah pembentukannya. Fenomenologi transcendental membedakan ciri-ciri utama kesadaran hingga sampai pada pemahaman hakiki dari pengalaman (Kuswarno, 2009; Tumirin dan Abdurahim, 2015).

Menurut Kamayanti (2016, hal. 153) dalam menganalisis hasil penelitian menggunakan fenomenologi transendental, peneliti dapat melakukan analisis data dengan mengidentifikasi lima unsur yang meliputi noema, epochelbracketing, noesis, intentional analysis, dan eidetic reduction. Peneliti melakukan analisis secara responsif terhadap tanggapan informan atas suatu pertanyaan. Peneliti menangkap apa yang tampak (noema). Berdasarkan noema, peneliti kemudian melakukan bracketing yakni menyibak apa yang ada di balik noema tersebut. Kemudian, peneliti dapat memperoleh noesis atau makna yang lebih mendalam dari noema. Langkah selanjutnya peneliti dapat memahami bagaimana noesis membentuk noema. Langkah ini disebut intentional analysis. Intentional analysis merupakan pemahaman peneliti terkait bagaimana proses bracketing dapat mengungkap bagaimana noesis membentuk noema. Setelah keseluruhan unsur terpenuhi, maka selanjutnya peneliti dapat memperoleh penggabungan dari keseluruhan proses tersebut, yaitu eidetic reduction. Proses penting dari fenomenologi terletak pada bracketing oleh peneliti. Kemampuan peneliti dalam menyikapi tanggapan informan akan menentukan sejauh mana kedalaman penggalian data. Fenomenologi dinyatakan sudah mencapai kesadaran terdalam apabila sudah mencapai titik jenuh atau lebih tepatnya tidak ditemukan bracketing baru.

\section{Metode Penelitian}

Penelitian ini menggunakan pendekatan fenomenologi. Alasan metode dan teknik penelitian dipilih karena masalah yang dikaji menyangkut makna biaya pembelian bandeng lelangan di Pasar Bandeng. Pendekatan fenomenologi digunakan untuk menemukan makna fenomena yang tampak di lapangan dapat diinterpretasi makna dan isinya lebih dalam. 


\subsection{Lokasi Penelitian}

Lokasi penelitian di Kabupaten Gresik. Informasi informan diperoleh dari kantor BAPPEDA untuk mengetahui alamat para informannya dan kemudian penelitian berikutnya berapa di kantor atau rumah para informan. Lokasi penelitian ditetapkan berdasarkan tujuan, yaitu untuk mengungkapkan harga yang terkandung dalam ikan Bandeng Lelangan.

\subsection{Penentuan Informan/Unit Analisis}

Penelitian ini pada dasarnya adalah upaya memperoleh informasi yang detail dan mendalam dari orang-orang yang berkaitan langsung dengan Ikan Bandeng Lelangan. Karena masalah yang diteliti berkaitan dengan harga bandeng lelangan, maka informan yang terkait adalah orang yang berkaitan langsung dengan Bandeng Lelangan yaitu petani tambak Ikan Bandeng.

\subsection{Teknik Pengumpulan Data}

Teknik pengumpulan data dalam penelitian ini akan dilakukan melalui teknik observasi dan wawancara. Secara intensif teknik observasi ini digunakan untuk memperoleh data mengenai komponen apa saja yang terkandung dalam harga ikan bandeng Lelangan. Dalam hal ini jenis observasi yang digunakan adalah observasi non sistematis, maksudnya tidak menggunakan pedoman buku, tetapi pengamatan dilakukan secara spontan, dengan cara mengamati apa adanya yaitu peneliti mengikuti acara Kontes Bandeng. Teknik wawancara digunakan untuk memperoleh data utama yang berupa ucapan, pikiran perasaan dan tindakan dari petani bandeng lelangan diharapkan akan lebih mudah diperoleh. Peneliti tetap memiliki pedoman wawancara tersebut bersifat fleksibel, sewaktu-waktu dapat berubah sesuai dengan perkembangan data yang terjadi di lapangan. Namun, fleksibelitas tersebut tetap mengacu pada fokus penelitian yaitu mengungkap makna harga ikan bandeng lelangan.

Dalam pelaksanaan wawancara tersebut dapat dilakukan baik di lingkungan Kantor di Rumah atau dimana saja yang dipandang tepat untuk menggali data agar sesuai dengan konteksnya. Sewaktuwaktu antara peneliti dan responden menyepakati waktu untuk melakukan wawancara, atau secara spontan peneliti meminta penjelasan mengenai suatu peristiwa yang dipandang perlu dan erat kaitannya dengan harga bandeng lelangan. Serta pada saat melakukan wawancara, peneliti mencatat data yang dipandang perlu sebagai data penelitian, dan merekam pembicaraan sumber atas persetujuannya terlebih dahulu.

\subsection{Pengumpulan Data Penelitian}

Penelitian ini dilakukan melalui pengumpulan data, didasarkan atas petunjuk-petunjuk dalam penelitian kualitatif. Teknik tersebut secara berurutan terdiri dan tiga tahapan, sebagai berikut: (1) orientasi, maksudnya adalah mulai dan penjajakan surat ijin penelitian dari BAPPEDA untuk melakukan surve ke Dinas Perekonomian kabupaten Gresik, (2) eksplorasi, yaitu menggali data dari petani tambak ikan bandeng lelangan melalui observasi dan wawancara (3) pengecekan, yaitu suatu tahap uji kritis terhadap data sementara yang diperoleh dari para informan.

\subsection{Analisis Data Penelitian}

Pelaksanaan penelitian ini menggunakan pendekatan fenomenologis, diupayakan pula terjadi proses reduksi, interpretasi, dan analisis data dengan mengikuti alur pendekatan tersebut. Proses reduksi dilakukan untuk mencari inti atau pokok persoalan dari data yang diperoleh. Untuk menginterpretasi data dilakukan kembali hasil reduksi sebagai bahan untuk menganalisis atau menyimpulkan hasil- hasil temuan.

\section{Hasil Penelitian}

\subsection{Sejarah Pasar Bandeng}


Pasar Bandeng merupakan tradisi menjelang lebaran di kota Gresik yang dilaksanakan pada malam 27 hingga malam 28 Ramadhan. Berdasarkan catatan sejarah, mulanya pasar bandeng hadir untuk memenuhi kebutuhan para santri Sunan Giri di Pondok Pesantren Giri Kedaton, saat ini dikenal dengan Desa Sidomukti Kecamatan Kebomas Kabupaten Gresik. Tradisi mudik menjelang lebaran dan pulang ke kampung halaman untuk berlebaran, umumnya dimanfaatkan para santri turun bukit menuju Kota Gresik untuk mencari oleh-oleh yang menjadi khas Gresik. Kala itu olahan bandeng menjadi khas Gresik sehingga banyak santri yang memilih bandeng untuk dibawa pulang sebagai oleh-oleh.

Sumber lain menyebutkan, Pasar Bandeng dikaitkan dengan sejarah perjalanan Sunan Giri pada malam terakhir bulan Ramadan. Saat itu, Sunan Giri melanjutkan perjalanan dari Giri ke sebuah mushalla di sekitar Pasar Gresik sekarang. Pengikut Sunan Giri yang berjumlah banyak itu kemudian membuat pasar dadakan yang konon banyak memperjualbelikan ikan Bandeng.

Ada pula yang menyebutkan bahwa tradisi Pasar Bandeng mulai dikenal masyarakat luas hingga luar pulau pada masa Syekh Djalaluddin (Buyut Senggulu) sekitar tahun 1600 yang merupakan ulama keturunan Sunan Giri. Hal ini terjadi dengan adanya hubungan antara Gresik dan Palembang yakni dari keluarga Kyai Qomis (Palembang) menantu Buyut Senggulu yang bersilaturahmi kepada Syekh Djalaluddin (Buyut Senggulu) setiap menjelang lebaran.

Buyut Senggulu memiliki tiga orang anak, semuanya perempuan, yaitu Nyai Mas, Nyai Anger, dan Nyai Werugil. Nyai Mas bersuamikan Kyai Qomis Tunggulwulung, keturunan Kerajaan Palembang. Kyai Qomis merupakan ahli kanuragan yang sangat sakti. Dialah yang menjaga keamanan Gresik dari orang-orang luar yang hendak mengacau Gresik dengan ilmunya. Nyai Mas dan Kyai Qomis inilah yang melahirkan seorang anak yang di kemudian hari menjadi Bupati pertama Gresik, yaitu Mbah Pusponegoro.

Dikisahkan pula, hubungan antara Gresik dan Palembang pada zaman itu sangat erat. Sehingga keluarga Kyai Qomis dari Palembang setiap menjelang Hari Raya selalu sowan ke Buyut Senggulu. Masyarakat Gresik menyambut rombongan keluarga Palembang dengan suka cita. Karena banyaknya tamu yang hadir, masyarakat Gresik kemudian berjualan oleh-oleh berupa aneka macam makanan dan cinderamata di sepanjang jalan yang sekarang bernama Jl. H. Samanhudi.

Karena Gresik merupakan penghasil ikan bandeng, maka pada saat keramaian itu juga dijajakan ikan bandeng kepada rombongan tamu dari Palembang itu tadi. Nah, diduga inilah yang kemudian berkembang menjadi tradisi Pasar Bandeng sebagaimana yang dikenal sekarang ini. Buyut Senggulu memang tidak memiliki keistimewaan khusus, hanya seorang ahli dakwah dan orang kepercayaan Sunan Giri VII. Namun Buyut Senggulu meninggalkan tradisi bagi masyarakat Gresik yang masih dilakukan hingga sekarang, yaitu Pasar Bandeng.

Di Pasar Bandeng, Umumnya bandeng yang dijual merupakan bandeng segar yang baru dientas (diambil) dari tambak. Setiap tahunnya gebyar pasar bandeng ini selalu diramaikan dengan acara pelelangan. Bandeng yang akan dilelang mulai dari ukuran sedang hingga bandeng besar hingga kawak. Khusus bandeng kawak satu ekor beratnya bisa mencapai lebih dari $10 \mathrm{~kg}$. Bukan hal mengherankan apabila harganya mencapai jutaan rupiah. Saat ini bukan hanya ikan bandeng yang diperjualbelikan, namun juga dimeriahkan dengan jual beli barang kebutuhan lainnya seperti pakaian, makanan, mainan anak-anak, perlengkapan ibadah, hewan peliharaan, hingga aksesoris.

Kegiatan rutin setiap tahun yang telah dilangsungkan selama ratusan tahun di kota Gresik ini selalu diadakan mulai dari jalan Raden Santri (Utara alun-alun Gresik) hingga jalan Gubernur Suryo kurang lebih sepanjang 2 kilometer. Riyoyoan (Lebaran dalam bahasa Gresik) kurang lengkap rasanya sebelum adanya hidangan masakan bandeng di rumah. Terlebih hidangan masakan bandeng umumnya juga dibawa ke langgar, surau, atau musholla terdekat sebagai syukuran dan nantinya akan dimakan bersama masyarakat dalam sebuah lengser atau talam (Semacam piring raksasa). Semakin lengkap nuansa lebaran dengan saling berbagi dan bersilaturrahmi.

\subsection{Budidaya Ikan Bandeng}

Pengembangan ikan bandeng sebagai salah satu pendorong peningkatan produksi perikanan perlu dicermati secara rasional. Potensi lahan yang cukup luas merupakan modal penting, namun masih terdapat kendala pada pertumbuhan penduduk, sehingga konversi lahan tidak terhindarkan. Pengembangan luas lahan tambak budidaya bandeng di Indonesia banyak terbentur dengan konversi lahan. Konversi lahan tambak ke penggunaan lainnya, berdampak pada ekstensifnya pembukaan lahan 
mangrove untuk lahan pertambakan baru (Mulyawan, Zamroni, dan Priyatna, 2017). Berikut adalah pernyataan dari Bapak Bashori selaku narasumber Petambak Bandeng Kawak.

"Tambake paling gak 3 hektar tapi yo gak di gawe iwak lelangan kabeh, kok menggo isi 100 ekor ngunu yo rugi, wong sewane tambak iku 30 juta pertahun. Nang ngingune sampek 4 tahun 5 tahun, yo ancen gak digawe khusus iwak lelangan, ibarat ngunu selingan lah dari 100 ekor mau di jukut 10 ekor gawe lelang engko ne onok pasar bandeng yo dijukut seng gede 3 ekor. Nek digawe khusus yo rugi."

Menurut pernyataan diatas untuk budidaya ikan bandeng lelangan tidak mudah, butuh kesabaran dan ketelatenan yang ekstra. Bukan hanya itu saja, biaya untuk makan dan penggantian airnya juga harus diganti lebih sering dibanding ikan yang dibudidaya biasa bukan untuk dilelang. Butuh waktu hingga 5 tahun lebih untuk membudidayakan hingga mencapai berat melebihi $4 \mathrm{~kg}$ satu ekor dengan demikian harga ikan bandeng lelangan tidak begitu mahal bagi yang menjualnya dikarenakan membudidayakannya cukup rumit.

Jika tambak seluas 3 hektar hanya digunakan untuk bandeng lelangan, justru rugi besar karena hanya dipanen beberapa tahun sekali. Meskipun ketika dijual dengan Harga jualnya lebih tinggi dibandingkan dengan bandeng pada umumnya. Jika dibuat selingan bandeng yang dibudidayakan biasa akan berkembang bersama-sama dan itu lebih menguntungkan dibandingkan hanya membudidayakan bandeng lelangan. Bapak Bashori berkata:

Yo oleh hadiah 20 juta teko penyelenggara, yo gak sumbut ambek seng digawe bandani selama nggedekno iwak lelangan iki mau, yo butuh sabar ambek telaten ngingu ngunu iku sak wulan diliar engko nek wes rodok gede di ingu mane sampek 4 wulan di pakani sak wulan diliar maneh.

Dari kalimat yang diutarakan beliau tentu saja hadiah yang diberikan pihak panitia tidak sesuai dengan apa yang sudah dikeluarkan selama masa perawatan. Biaya sewa tambak saja sebesar Rp30.000.000 per tahun dan itu berlangsung 4 sampai 5 tahun untuk membesarkan Ikan Bandeng kawak. kemudian belum ditambah dengan tenaga, pakan, pupuk dan bibitnya tentu melebihi dari hadiah tersebut. Akan tetapi Bapak Bashori tidak memperdulikan hal itu karena hadiah yang diberikan panitia dianggap hanyalah sebagai upah saja bukan hadiah.

Waktu yang lama pun menjadi penentu perkembangan ikan bandeng karena jika waktu berlangsung cukup pendek maka bandeng yang dihasilkan pun tidak terlalu besar, kalau waktu budidayanya agak lama air dan tanahnya mendukung maka ikan akan bertambah besar dan sesuai kriteria yang diinginkan panitia pasar bandeng.

Jika para petani tambak berfokus hanya membesarkan ikan bandeng sebesar 4 Kilogram keatas maka hanya kerugian yang dialaminya karena biaya sewa tambak yang tidak murah dan waktu yang cukup lama menjadi pemicu banyak petani tambak untuk malas membudidayakannya.

"Sekarang kita kalau mikirnya hanya uang membudidayakan bandeng dengan rentang usia sekian lama uangnya cuman sekian, ya mending jual yang kecil aja mbak lebih menguntungkan."

Dari pernyataan diatas jelas bahwa biaya yang dikeluarkan untuk membudidayakan ikan bandeng Kawak melebihi dari uang perolehan dari hadiah kontes. Kalau satu tahun bisa menjual bandeng kecil sebanyak 100 ekor dengan harga perekornya Rp45.000 maka dapat Menghasilkan Rp45.000.000 sedangkan kalau hanya bandeng yang berukuran besar seberat $8 \mathrm{Kg}$ dihargai Rp15.000.000 maka jelas tidak sebanding dengan harga bandeng kecil yang dijual pertahunnya.

\subsection{Melestarikan Tradisi}

Keseluruhan benda material dan gagasan yang berasal dari masa lalu namun benar-benar masih ada kini, belum dihancurkan, dirusak atau dilupakan. Disini tradisi hanya berarti warisan, apa yang sebenarnya tersisa dari masa lalu. (Piotr, 2011) suatu gambaran sikap dan perilaku manusia yang sudah 
berproses dalam waktu lama dan dilakukan secara turun temurun dimulai dari nenek moyang. Tradisi yang sudah membudaya akan menjadi sumber dalam berakhlak dan berbudi pekerti seseorang (Coomans, 1987).

\section{"Ya memang tradisi tiap tahun"}

Bapak Yoyok salah satu warga Yosowilangun, merupakan peserta kontes bandeng yang baru saja mengikuti Kontes ini. Menurut pengakuan bapak Yoyok tersebut alasan pertamanya adalah untuk melestarikan tradisi turun temurun ini. Sebagai warga Gresik asli tentu memiliki keinginan yang kuat untuk melestarikan budaya ini karena Pasar Bandeng ini terjadi hanya satu tahun sekali dan yang menghadiripun dari berbagai kalangan mulai dari tua, muda anak-anak, warga Gresik bahkan luar Gresik pun ikut meramaikan acara ini. Tentu ini menjadi salah satu momentum terbesar warga Gresik untuk menyambut Hari Raya Idul Fitri.

"Bapak Bupati pun mengatakan: "Kami di Pemerintah Kabupaten Gresik senantiasa berupaya mempertahankan warisan leluhur dengan mengadakan festival pasar bandeng menjelang berakhirnya Bulan Ramadhan.”

Dengan demikian warga Gresik pun akan selalu melestarikan budaya Pasar Bandeng karena warga Gresik sendiri jika lebaran yang dihidangkan tidak ada Bandengnya seperti ada yang kurang, begitu juga dengan para petani tambak ikan Bandeng sudah mepersiapkan Bandeng berukuran besar (kawak) untuk diikutkan untuk tahun kemudian.

\subsection{Perbedaan Lelang dengan Kontes Ikan Bandeng}

Pasar bandeng adalah sebuah tradisi yang erat kaitannya dengan jual beli, banyak masyarakat yang mengambil keuntungan dari tradisi ini. Mulai dari berjualan pakaian, Makanan khas kota Gresik, jajanan zaman dulu, berbagai olahan Ikan Bandeng, hewan ternak dan lain sebagainya. Didalam tradisi ini terdapat satu acara yang ditunggu-tunggu oleh para pengunjung yaitu Lelang Bandeng, dimana lelang itu menampilkan Bandeng-bandeng berukuran Kawak alias Besar mulai dari $5 \mathrm{Kg}$ sampai $9 \mathrm{Kg}$.

Berdasarkan data pemerintahan pada tahun 2010 acara lelang Bandeng ini mampu mengumpulkan dana sebesar Rp. 46.500.000 Dua bandeng maskot hasil budidaya petambak tradisional dari Gresik dilelang Rp 11,5 juta. Bandeng seberat 8,2 kilogram milik Askur, warga Pangkahkulon, Kecamatan Ujungpangkah, terjual Rp 6 juta dengan penawar terakhir Pejabat Sementara Bupati Gresik M Najikh. Bandeng milik Sirojul Munir, warga Tanjung Wedoro, Mengare, Kecamatan Bungah, dengan berat $6 \mathrm{~kg}$ terjual Rp 5,5 juta dengan pemenang lelang Bank Jatim Cabang Gresik.

Enam bandeng kawak ukuran besar yang dilelang dengan sistem cash and carry laku Rp 35 juta. Bandeng seberat 7 kilogram ditawar terakhir oleh Saifullah Yusuf Rp 5,5 juta. Bandeng seberat 7,2 kilogram ditawar Kelompok Bagian Pemerintah Kabupaten Gresik senilai Rp 5 juta. Bandeng seberat 7,6 kilogram dibeli DPRD Gresik dengan nilai Rp 5,5 juta.

Bandeng seberat 8,4 kilogram menjadi milik Kepala Kepolisian Resort Gresik Ajun Komisaris Besar Jakub Prajogo dengan nilai Rp 5,5 juta. Gabungan Dinas Pemkab Gresik memenangi lelang bandeng seberat 9,4 kilogram senilai Rp 6 juta. Bandeng kawak terbesar seberat 11 kilogram dimenangi gabungan camat dan badan Pemkab Gresik senilai Rp 7,5 juta.

Selain lelang bandeng maskot dan bandeng kawak, ada juga lelang hiburan. Ada 10 bandeng yang dihadiahkan kepada masyarakat yang bisa menjawab pertanyaan dari undangan istimewa, seperti wakil gubernur dan Muspida Kabupaten Gresik.

Dalam perjalanan waktu, pasar bandeng yang semula hanya berisikan aktivitas jual-beli ikan bandeng, dalam beberapa tahun terakhir dibuatkan kontes. Kontes yang diselenggarakan Pemerintah Kabupaten Gresik, digelar untuk menilai bandeng berukuran paling besar. Kontes tersebut diperuntukkan khusus bagi petani tambak asli Gresik, dengan ikan bandeng yang juga dipelihara di tambak-tambak yang ada di wilayah Gresik. Kontes tahun ini diadakan Rabu malam.

Pergantian dari lelang menjadi kontes Bandeng memang tidak banyak yang mengetahui, karena hal pertama yang erat kaitannya dengan pasar bandeng adalah lelangnya ikan bandeng kawak. Akan 
tetapi perubahan tersebut sudah menjadi keputusan Pemerintahan Daerah dikarenakan banyak hal. Seperti yang diutarakan Bapak Yoyok kontestan bandeng.

"Yang saya tahu ya mbak memang sudah lama lelang itu berubah menjadi kontes. Nah kalau lelang mungkin yang bisa beli kan cuma orang berduit saja, kalau kontes kan PEMDA mengapresiasi para petani tambak bandeng dengan memberi hadiah sejumlah uang yang dimana ikan bandeng tersebut akan disumbangkan ke yayasan atau pondok pesantren."

Menurut apa yang dikatakan bapak yoyok tersebut pergantian dari lelang menjadi kontes sudah tepat, karena yang bisa menikmati bandeng kawak hanyalah orang kalangan menengah keatas, dan untuk masalah uang yang didapat pun kurang begitu jelas arah kemananya. Jadi lebih baik untuk diganti menjadi kontes yang runtutan ceritanya lebih jelas dan terarah.

Selain itu pemerintahan daerah juga memberikan apresiasi terhadap para petambak Bandeng yang sudah bertahun-tahun membudidayakan ikan Bandeng meskipun menurut para petambak hadiah yang diberikan oleh pemerintah dikatakan kurang dari yang sudah dikeluarkan selama membesarkan ikan tersebut. Tapi mereka selaku pemenang merasa sangat bangga akan apa yang akan diperoleh setelah ini.

\subsection{Harga Ikan Bandeng}

Harga Ikan Bandeng di hari biasa memang tidak setinggi pada saat Pasar Bandeng, kalau setiap hari Ikan Bandeng yang dijual kisaran berat tidak sampai 1 kilogram dan harga perkilonya pun hanya Rp30.000 - Rp45.000.

Pada acara kali ini, harga bandeng bervariasi. Bandeng termurah yang berbobot $1 \mathrm{~kg}$ dihargai Rp45.000-60.000 perkilonya. Bandeng $2 \mathrm{~kg}$ dijual Rp110.000-120.000 perkilonya, dan bandeng $3 \mathrm{~kg}$ seharga Rp180.000-190.000 perkilonya.

"Semakin besar ukuran bandeng, tentu akan lebih mahal. Tapi biasanya, antara kami dan pembeli juga saling tawar-menawar, itu sudah biasa."

Dari penjelasan diatas bandeng yang semakin besar dihargai lebih mahal karena dalam pemeliharaannya semakin besar bandeng semakin mahal juga pembudidayaannya. Jika waktu yang ditempuh semakin lama tidak menutup kemungkinan biayanya juga semakin tinggi. Belum lagi tenaga dan pikiran yang harus memperhatikan perkembangan

Yang membuat harganya lebih tinggi daripada hari biasa itu adalah tradisinya dimana setiap ikan bandeng yang dijual di acara tersebut rata-rata sudah disiapkan khusus ikan bandeng yang beratnya diatas 1 Kilogram perekornya. Jadi ikan bandeng yang dijual usianya lebih dari satu tahun karena naiknya berat bandeng setiap tahunnya adalah sekitar 1 kilogram.

Akan tetapi berbeda pendapat dengan salah satu pembeli bandeng yang bernama Rahmawati mengatakan:

Sekarang sudah banyak tambak yang dijadikan areal perumahan, bangunan-bangunan, maupun pabrik. Jadi saya kira harga-harga itu masih cukup wajar

Gresik telah bertransformasi menjadi Kota Industri dimana banyak sekali lahan tambak, sawah dan perkebunan yang berubah menjadi pabrik-pabrik besar para pemuda yang seharusnya mewarisi ilmu pertambakan atau perkebunan seakan acuh dan memilih untuk menjadi karyawan yang penghasilannya lebih jelas. Maka dari itu hanya para orang tua yang mempertahankan dunia pembudidayaan ikan, ikan yang dibudidayakan semakin tahun semakin kecil dan terbilang berkurang jumlahnya.

Menurut pemaparan Rahmawati harga ikan bandeng justru wajar-wajar saja karena menyadari jumlah petani tambak ikan bandeng yang semakin berkurang dan banyak lahan yang berubah menjadi area perkantoran. Harga yang ditawarkan oleh penjual jika terlalu tinggi di Pasaran akan tidak laku, jadi menurut mereka lebih baik keuntungannya standard saja daripada tidak bisa balik modal. 


\subsection{Reputasi dan Kebanggaan}

Reputasi bukanlah hal yang bisa langsung dimiliki atau dibangun seseorang secara instan. Membangun reputasi membutuhkan proses yang panjang dengan performa yang bagus di suatu bidang. Oleh karena itu, tidak mungkin seseorang bisa langsung secara tiba-tiba dikenal mempunyai reputasi bagus.

Reputasi adalah bentuk Kepercayaan yang kita bangun berdasarkan apa yang sudah kita lakukan. Menjaga reputasi sangat penting kaitannya dengan bisnis, apabila reputasi baik telah terbangun maka bisnis yang akan dijalani pun akan mudah diterima kalayak luas seperti yang diungkap oleh Bapak Yoyok

"Bangga mbak, kebanggaannya itu dari sisi prestise."

Prestise kalau diartikan kedalam Bahasa Indonesia adalah Nama baik atau reputasi, untuk membangun reputasi tidak bisa secara instant atau langsung dan reputasipun tidak bias dibeli dengan uang. Reputasi adalah salah satu tujuan yang didapat petani tambak untuk mengembangkan bisnisnya.

Sunter (1993) berkeyakinan bahwa pada masa akan datang hanya dengan citra, maka pelanggan akan dapat membedakan sebuah produk dengan produk lainnya. Oleh karena itu bagi perusahaan jasa memiliki citra yang baik adalah sangat penting. Dengan konsep citra produk yang baik ia dapat melengkapkan identitas yang baik pula dan pada akhirnya dapat mengarahkan kepada kesadaran yang tinggi, loyalitas, dan reputasi yang baik. Abdillah mengatakan:

Gembira, bersyukur mbak bangga juga nama usaha saya menjadi semakin maju.

Rasa bangga akan mendapatkan juara adalah bentuk kepuasan tidak terkira bagi petani tambak bandeng, meskipun hadiahnya tidak seberapa berarti bagi petani tambak karena penghargaan yang paling penting bukan uang melainkan nama baik yang selalu terpampang di berbagai media massa. Seperti usaha milik Andilah yang diberi nama Hasil 70 yang masih terkenal di daerah Sembayat dan sekitarnya dengan harapan nama hasil 70 itu akan terkenal dimana-mana.

Perasaan bangga dan bahagia tentu meliputi siapa saja yang bisa menjadi juara pertama, tak terkecuali warga Sembayat tersebut bisa berada diantara jajaran Bapak Bupati dan Wakil Bupati Namanya dikenal seluruh masyarakat kota Gresik, tayang dibeberapa Televisi Swasta, Media Massa dan juga media Sosial.

\subsection{Relasi Bisnis}

Setiap pebisnis ingin usahanya dapat berjalan dengan baik, dapat bertahan di tengah persaingan bisnis yang keras dan sengit serta berkembang. bisnis jangka panjang tidak bisa dilepaskan dari adanya relasi bisnis. Dengan memiliki relasi atau jaringan bisnis yang baik dan terpercaya akan bisa menopang bisnis kita kedepannya. Hubungan bisnis ini yang menjadi pondasi kuat bisnis kita untuk bertahan hidup.

Ketika orang berbisnis yang dibutuhkan tak hanya ketersediaan produk atau jasa, kemudian adanya konsumen atau klien. Namun lebih dari itu terdapatnya jaringan bisnis yang mampu menopang kehidupan berbisnis. Relasi bisnis dimaksudkan sebagai awal pembentukan jaringan untuk kepentingan bisnis di masa depan. Relasi bisnis bisa dibangun pada pertemuan bisnis yang melibatkan banyak pengusaha dengan proses saling berkenalan. Ibu Hj. Fauziyah mengungkapkan:

Ya cari nama siapa tahu habis ini usaha saya semakin terkenal dan semakin maju juga mbak, kayak batu loncat lah mbak.

Baginya Reputasi akan diperoleh jika Ikan Bandengnya sudah tampil menjadi pemenang di Kontes Ikan Bandeng yang rutin diselenggarakan oleh Pemerintah Kabupaten Gresik untuk meningkatkan Ekonomi para petani tambak dimana profesi tersebut telah melekat dengan Kota Gresik. Setelah mendapatkan Reputasi yang baik lahirlah Relasi Bisnis itulah yang diharapkan Ibu Hj. Fauziyah demi keberlanjutan Bisnisnya dalam dunia Pertambakan atau jual-beli ikan Bandeng yang berukuran besar atau yang kecil. 
Karena $\mathrm{Hj}$. Fauziyah baru pertama kali mengikuti kontes ini maka yang diharapkan adalah kemajuan usahanya dan menarik banyak minat pelanggan untuk membeli ikan bandeng disana. Bukan hanya $\mathrm{Hj}$. Fauziyah saja yang menginginkan hal itu bapak Andillah yang Usahanya diberi nama Hasil 70 pun bertujuan demikian untuk mengikuti kontes ini, meskipun beliau sudah 3 tahun ini mengikuti kontes beliau mengaku setelah mengikuti kontes ini jadi lebih banyak yang membeli Bandeng miliknya.

\section{Kesimpulan}

Berdasarkan uraian penjelasan yang telah disampaikan diatas, terungkap Makna Harga Kontes Ikan Bandeng Dalam Tradisi Pasar Bandeng adalah para petani tambak memiliki perspektif tersendiri dalam memaknai biaya yang harus dikeluarkan untuk mengikuti Kontes Ikan Bandeng dalam Tradisi Pasar Bandeng sebagai berikut: (1) Membudidayakan ikan bandeng butuh waktu yang lama tidak cukup hanya 1 atau 2 tahun saja, usia bandeng yang diikutkan kontes hampir rata-rata 5 tahun keatas. Selain itu pembudidayaannya butuh kesabaran dan ketelitian yang penuh jika tidak teliti maka ikan bandeng tidak akan bisa besar bahkan bisa mati; (2) Melestarikan tradisi menjadi tujuan para petani tambak dan juga Pemerintahan Kabupaten Gresik karena dengan adanya tradisi tersebut berdampak positif untuk meningkatkan pendapatan ekonomi masyarakat. (3) Istilah Lelang Bandeng sudah berubah menjadi Kontes bandeng dikarenakan, kontes bandeng lebih mengapresiasi para petani tambak dengan meberi hadiah sejumlah uang daripada melelangnya tapi uang yang didapatkan tidak diketahui kejelasannya. (4) Harga ikan bandeng yang diperjulbelikan di acara tersebut berbeda dengan hari biasa, bedanya adalah bandeng yang dijual di pasar bandeng lebih besar dan harganyapun lebih tinggi. Tingginya harga bandeng dikarenakan usia bandeng yang lebih tua dan rasanya juga semakin empuk. (5) Para pemenang kontes bandeng secara langsung reputasinya menjadi baik. Maka salah satu tujuan untuk mengikuti kontes tersebut adalah mencari reputasi untuk menarik relasi bisnis demi keberlanjutan bisnis mereka.

Makna harga Kontes Ikan Bandeng dalam Tradisi Pasar Bandeng secara kontekstual adalah untuk meningkatkan Pendapatan ekonomi masyarakat. Pemerintahan. Dengan adanya pasar bandeng masyarakat Gresik khususnya para petani tambak dapat memperoleh laba lebih tinggi dari hari biasanya, begitu juga dengan para penjual lainnya pada saat pasar bandeng juga meraup keuntungan lebih banyak karena seluruh masyarakat Gresik berduyun-duyun ingin menyaksikan ikan Bandeng dengan ukuran besar.

\section{Daftar Pustaka}

Adian, D. G. 2010. Pengantar fenomenologi: Penerbit Koekosan.

Coomans, M. 1987. Manusia Daya: dahulu, sekarang, masa depan: Gramedia.

Kamayanti, A. 2016. Metodologi Penelitian Kualitatif Akuntansi: Pengantar Religiositas Keilmuan. Jakarta: Yayasan Rumah Peneleh.

Kuswarno, E. 2009. Metodologi penelitian komunikasi fenomenologi.

Mulyawan, I., Zamroni, A., \& Priyatna, F. N. 2017. Kajian Keberlanjutan Pengelolaan Budidaya Ikan Bandeng di Gresik. Jurnal Kebijakan Sosial Ekonomi Kelautan dan Perikanan, 6(1), 25-35.

Piotr, S. 2011. Sosiologi Perubahan Sosial. Jakarta: Prenada.

Sunter, C. 1993. In Van Heerden, Cornelius H. dan Puth, Gustav. 1995. Factors that Determine the Corporate Image of South African Banking Institutions. International Journal of Bank Marketing, 13(3), 12-17.

Tumirin, T., \& Abdurahim, A. 2015. Makna Biaya Dalam Upacara Rambu Solo. Jurnal Akuntansi Multiparadigma, 6(2), 175-184. 